\title{
As vozes do escrito: sobre leitura e escrita
}

\author{
João Gabriel Lima da Silva, ${ }^{\text {, } \star ~ T h i a g o ~ J o s e ́ ~ d e ~ F r a n c o ~ d a ~ S i l v a ~}{ }^{I I}$ \\ ${ }^{I}$ Universidade Federal do Rio de Janeiro, Rio de Janeiro, RJ, Brasil \\ ${ }^{I I}$ Universidade Federal Fluminense, Niterói, RJ, Brasil
}

\begin{abstract}
Resumo
Esse artigo busca responder a seguinte questão: o que pode a escrita fazer frente à voz? Para esse fim, os autores pesquisam nas obras do filósofo alemão Walter Benjamin o conceito de origem para argumentar que a escrita ao mesmo tempo salva e aniquila a presença e a potência da voz. Os autores exploram não apenas os métodos para a procura das origens mas também apresentam e discutem a história da escrita e a experiência de ouvir vozes no ato da leitura. Através do diálogo com a história da escrita, o intuito do artigo é apresentar uma concepção de escrita baseada em conceitos benjaminianos.
\end{abstract}

Palavras-chave: escrita; leitura; voz; origem; Benjamin.

\section{Voices of the writing: on reading and writing}

\begin{abstract}
This paper aims to answer the following question: what writing can do in the face of voice? For this purpose, the authors research the concept of origin within the works of the German philosopher Walter Benjamin in order to argue that at the same time the writing saves and annihilates the presence and the power of the voice. The authors explore not only methods to search origins but also present and discuss the history of writing and the experience of listening voices in psychosis and in the act of reading.
\end{abstract}

Keywords: writing; reading; voice; origin; Benjamin.

\section{Introdução}

Este artigo se dedica a responder à seguinte pergunta, ela em si tão difícil: o que realiza a escrita frente à voz? Para responder a essa questão, empreenderemos, nesse trabalho, um retorno às origens da escrita. Nosso trabalho parte de duas constatações. A primeira delas é bem simples: quando lemos, ouvimos uma voz que nos narra. O narrador presente na leitura silenciosa nos questiona sobre a materialidade da voz ouvida. A segunda é a de que o ato de escrever subtrai o poder da voz. Em um caso, uma voz é gerada pela escrita; em outro, uma voz é aniquilada. Já nesse pequeno prólogo apresentaremos um esboço de resposta à questão que guia nosso artigo: "ao mesmo tempo em que a escrita torna possível a restituição parcial de uma voz, ela aniquila o poder vocal". Há, todavia, um longo caminho a percorrer até que essa resposta possa fazer algum sentido.

\section{Definição de escrita e o problema das origens}

Não raro se opõe escrita à voz. Temos acesso ao que é antigo por uma escrita, sem dúvida, porém poucas obras antigas nasceram da escrita. Sabemos hoje que tanto a Ilíada quanto a Odisseia são obras compostas por muitos autores desconhecidos do que chamam de tradição oral, entre eles - talvez apenas um compilador de tudo isso - está a efígie de Homero. A imensa maioria das canções gesta, as sagas anglo-saxãs e islandesas, as canções dos jograis ambulantes, boa parte do material do medievo reunido pelos monges e clérigos foi igualmente obra de muitos autores distintos, muitas vezes analfabetos. É bastante improvável que alguém tenha tido contato com esse material hoje em dia pela combinação pura entre voz e memória. Ao contrário, nós o acessamos, obviamente,

\footnotetext{
^Endereço para correspondência: Universidade Federal do Rio de Janeiro. Centro de Filosofia e Ciências Humanas. Av. Pasteur, 250 - Urca, Rio de Janeiro, R. - Brasil. CEP: 22290-240.E-mail: joaogabriellimadasilva@gmail.com, sthiagofranco@yahoo.com.br
}

porque está escrito, mas em sua “origem” está a voz, que é salva pela escrita. Eis a definição precária de escrita que convém desenvolver: escrita é o que salva uma voz.

Se a voz está na origem da escrita, resta saber qual é o sentido de origem a que nos referimos. Dado que há um evento no mundo, seja banal ou grandioso, como se deve procurar pela origem desse evento? Os historiadores, narradores e mais recentemente os cientistas buscam a origem de formas distintas.

$\mathrm{O}$ mito parece ter sido o primeiro modo de encontro - ou fundação - de uma origem. Tomemos nossos ancestrais filosóficos, os gregos. Desde a mais elementar distinção entre Caos e Eros, passando pelo mito de Urano e Gaia, a rebelião de Cronos e por fim a insurgência de Zeus e sua tropa, há em todos esses mitos uma sofisticação ímpar na captura e elaboração de uma origem para o mundo. A narrativa bíblica é igualmente sofisticada no que toca à Criação: a nomeação das coisas, a costela de adão, o fruto proibido são meios muito satisfatórios para quem neles acredita - em sua tarefa de supor uma origem para a linguagem, para a mulher e para a moral. Contudo, somos tentados a concordar com K. K. Ruthven (1976): o mito, mais que feito para explicar, foi criado para maravilhar. As origens míticas de algum evento são sempre estrondosas, intrigantes e dificilmente respeitam o princípio da verossimilhança.

Outro modo de resolver o problema da origem dos eventos é o histórico. Heródoto, nomeado o primeiro historiador por ter ido além das crônicas e anais, não se importava diretamente em elucidar as razões dos fatos. Escrevia para relatar o que presenciava e também não deixava de registrar o que os homens a ele próximos estavam pensando. Heródoto narrava as histórias que ouvia, e se às vezes as explicava, não era com a intenção direta de encontrar a origem. Seu ofício era a transmissão da experi- 
ência: não apenas a sua, como também a alheia. Tal como dirá Hegel (1971, p. 153, tradução nossa) em sua Filosofia da História, "eles [Heródoto e os historiadores narrativos] simplesmente transferem o que se passava em frente aos seus olhos e o que seus espíritos compartilharam". São homens que não permitem que a busca pelas origens suplante o próprio prazer de contar e ouvir as estórias.

Porém, a partir de Tucídides e com toda força após o Iluminismo, a História começa a buscar cada vez mais explicações para cada evento ocorrido. A procura pela origem dos fatos, que em Heródoto não era mais que uma curiosidade do autor, passa a ser o objeto de estudo dos historiadores. A história passa a ser "reflexiva", nos dizeres de Hegel (1971, p. 154-155), ou de um modo ainda mais simples, a história ultrapassa a vida e a experiência do historiador. Com o Historicismo, a descrição - assim chamada - "objetiva" dos fatos e datas se tornou ao longo do tempo o mais "confiável” suporte de transmissão de uma experiência histórica. Não demorou muito até que a origem se tornasse apenas uma causa localizável no espaço e no tempo. Ora, quando tudo pode ser descrito objetivamente, trata-se apenas de uma questão de dedução lógica encontrar o que inequivocamente motivou tal ou qual evento. Também o futuro se torna tão dedutível quanto o passado.

$\mathrm{O}$ discurso científico tem igualmente seu método na captura da origem. Em sua forma resumida, o método científico não é mais que "fazer observações e então as comparar" (ATKINS, 2011, p. viii, tradução nossa). É verdade que não há apenas um método científico, mas, em geral, todos eles mantêm estas quatro etapas básicas: 1) "caracterização do objeto" através de observações, descrições e mensurações; 2) "a criação de uma hipótese" para o fenômeno observado; 3) a "predição", que é a ligação entre a hipótese e objeto - via dedução lógica, a fim de prever os resultados; 4) e finalmente a "experimentação", que deve provar ou refutar a teoria após a análise dos dados. ${ }^{1}$ Após a comprovação científica, acredita-se ter encontrado a causa (ou a origem) de um evento.

Em seu livro On Being: a scientist's exploration of the great questions of existence, o químico oxfordiano Peter Atkins (2011, p. xi, tradução nossa) afirma que a ciência pode explicar tudo caso o método científico seja utilizado com segurança: "[Quanto ao método científico], a que pode ser ele aplicado e quais são as suas limitações? Eu considero que não há nada que ele não possa iluminar". Diz o polêmico autor que se a ciência ainda não nos deu todas as respostas que precisamos, tão só os "medrosos de sua iluminação" afirmam que há alguma barreira intransponível (ATKINS, 2011, p. xi, tradução nossa). Ademais, Atkins evidencia - em uma metáfora bem humorada - que a ciência examina o gato, e não o tigre (Atkins, 2011); isto é, o método científico investiga os fenômenos "domesticados", em um laboratório, onde tudo pode ser testado e analisado com segurança. Os fenômenos selvagens, isso a ciência não pode capturar.

Para a história e elaboração da metodologia científica, ver Godfried-Smith (2003). Para as contradições, ver Feyerabend (2011).
Há, naturalmente, tantos métodos para alcançar a origem que passaríamos todo o artigo descrevendo as diferentes formas de abordá-los, o que nem de longe é nossa intenção. Porém, carece salientar que por mais que historiadores, narradores e cientistas se esforcem em sua pesquisa sobre a origem dos eventos, nem todos ignoram a insuficiência de seus métodos na apreensão da origem. Há algo que perturba a coerência do encaixe dos fatos, ainda que quando descritos aberta e confiavelmente. Alfred Jeanroy (1934, p. 80, tradução nossa), um dos grandes historiadores modernos de literatura medieval, argumenta em um capítulo chamado "O problema das origens":

Não se trata de demonstrar - há necessidade de dizer? que tais circunstâncias deveriam determinar fatalmente a produção poética que nós conhecemos. Há em toda criação artística uma parte de mistério que jamais perceberão as mais sutis pesquisas dos historiadores.

As palavras de Jeanroy podem ser estendidas a todo tipo de investigação. O "mistério", na verdade, não é um jardim oculto onde só Preste João poderia pisar. A existência do "mistério" significa ainda menos a necessidade de um Deus. Nada além: o mistério é o limite de cada método ao lidar com a origem. Ou como tão categoricamente disse Paul Feyerabend (2011, p. 67): "nenhuma teoria está em concordância com todos os fatos do seu domínio". Podemos constatar com segurança que nenhum discurso - científico, mítico, filosófico, místico - parece ter sido suficiente para sustentar e resolver a origem de todos os fatos a que se propuseram, ao menos até hoje.

\section{A salvação da origem}

Uma vez que abrimos mão de apreender o que é verdadeiramente original de um evento, podemos, com uma disposição bem mais humilde de espírito, conservar algo dessa origem material por uma operação que gostaríamos de sugerir, mas que ao mesmo tempo não é nada fácil de descrever objetivamente: a "salvação da origem", conceito haurido na obra de Walter Benjamin. ${ }^{2}$

Analisemos então as célebres Teses sobre o conceito de História, onde, na tese IX, Benjamin faz apelo à imagem do quadro de Paul Klee (1920), Angelus Novus. Diz Benjamin (1994, p. 266):

Há um quadro de Klee que se chama Angelus Novus. Representa um anjo que parece querer afastar-se de algo que ele encara fixamente. Seus olhos estão escancarados, sua boca dilatada, suas asas abertas. $\mathrm{O}$ anjo da história deve ter esse aspecto. Seu rosto está dirigido para o passado. Onde nós vemos uma cadeia de acontecimentos, ele vê uma catástrofe única, que acumula incansavelmente ruína sobre ruína e as dispersa a nossos pés. Ele gostaria de deter-se para acordar os mortos e juntar os fragmentos. Mas uma tempestade sopra do paraíso e prende-se em suas asas com tanta força que ele não pode mais fechá-las [...] Essa tempestade se chama progresso.

Mais que um instante parado no tempo e espaço solidamente construído, a origem é aquilo que "jamais cessa de se arruinar". O passado original não está pronto, ${ }^{2}$ Esse conceito foi localizado em Walter Benjamin por Jeanne-Marie Gagnebin (2009), em seu livro já paradigmático nos estudos benjaminianos no Brasil, "História e narração em Walter Benjamin".

Fractal, Rev. Psicol., v. 29 - n. 3, p. 231-238, 2017 
como um edifício, aberto à contemplação de suas estruturas. Ele está, muito ao contrário, em um campo completamente devastado, onde a cada instante novas ruínas são despejadas. Buscar uma origem é lançar-se a esses fragmentos esfarelados enquanto o tempo cronológico, o tempo do progresso, o tempo da rotina nos empurra para frente. Entre todos esses fragmentos empilhados desordenadamente, nós nos agarramos a uns poucos ao longo de nossa história e então construímos um belo sentido de vida que, aparentemente, conecta a grande maioria. Os muito excêntricos, tentamos esquecer ou rir deles; os mais terríveis, recalcamos.

Contudo, esses cacos não foram salvos em um tempo cronológico. Uma história do subúrbio diz de um menino que, após ter se atrapalhado com o fogo, retorna à sua casa incendiada. Sobre a mesa, encontra o relógio de plástico que ornava sua parede: o ponteiro das horas abraçou o dos minutos, impedindo que a contagem do tempo prosseguisse. O relógio - frente à tamanha intensidade - renunciou ao tempo cronológico que até então o girava. Para que algo da origem seja salvo, é preciso que um tempo intensivo se sobreponha ao tempo da rotina. J. M. Gagnebin (2009, p. 19, grifos nosso) nos diz:

É na densidade do histórico que surge o originário, intensidade destrutora das continuidades e das ordens pretensamente naturais, e intensidade salvadora também, pois reúne os elementos temporais díspares em uma outra figura possível, a de sua verdade. [...] A origem não está ligada a um aquém mítico ou a um além utópico a ser reencontrado apesar do tempo e apesar da história.

Até mesmo uma articuladora com a clareza de Gagnebin nos parece bem difícil ao tratar do conceito de origem. Dessa passagem, deve-se destacar ao menos isso: em primeiro lugar, que o originário tem uma "intensidade destruidora" das "continuidades": o domínio do tempo cronológico sobre suas atividades. A origem, para Benjamin, faz aparecer - na história - um tempo que não é do relógio, um tempo intensivo que destrói. Igualmente, a origem faz surgir uma "intensidade salvadora", que produz a coexistência de elementos que são distintos no nível cronológico (um exemplo fictício, o gosto de um bolo que alguém comeu na casa da avó aos sete anos de idade coexiste em suas lembranças com o instante do seu casamento). No instante em que uma ruína - parte da origem - se abate sobre o sujeito, ela pode tanto derruir o que ele é ou o que ele se reconhece quanto incorporar novos elementos em sua vida.

O trabalho com as origens de um evento não pode ser apenas a localização espaço-temporal ou a definição de uma causa que levaria a uma consequência. Mais do que isso, trata-se de "destituir" esses fragmentos de origem que foram salvos do lugar de destroços indispensáveis e "restituí-los" a uma outra dignidade original; é preciso "dispersá-los", "reuni-los" sob outro modo para que, quando novamente se arruínem, os cacos sejam outros; é preciso "destruí-los" ainda mais e então "construir" não somente outro futuro, mas sobretudo outra origem. ${ }^{3}$

\footnotetext{
3 "A obra de salvação do Ursprung (origem) é, portanto, ao mesmo tempo e inseparavelmente, obra de destituição e de restituição, de dispersão e de reunião, de
}

\section{História da escrita}

Foi dito que a escrita salva a voz e então as fizemos as primeiras considerações sobre o conceito de salvação de origem. Parece claro que estamos tentando sugerir que a "voz é a origem da escrita". Entretanto, isto não se dá apenas no plano de causa-consequência. A voz não causa a escrita por si mesma. Afirmamos sim que a escrita é uma forma de lidar com a voz que não para de se arruinar. Ou em outros termos, que a escrita lida com as "ruínas da voz". Nesse sentido, a voz está na origem da escrita - origem no sentido que acabamos de mencionar, repetimos, como aquilo que jamais cessa de se deixar salvar, de se desperdiçar.

Antes de sair afirmando novidades sobre a escrita, é preciso consultar os trabalhos dos linguistas e epígrafos, esses bravos homens que gastam o fio de sua vida trazendo luz às línguas mortas. Recentemente, o livro do australiano Steven R. Fischer, História da escrita (2009), condensou os resultados de novas investigações dos pesquisadores em uma obra ao mesmo tempo agradável e rigorosa.

O primeiro ponto que nos interessa é a "definição de escrita" do autor. ${ }^{4}$ Fischer compreende que as definições de escrita não são sempre as mesmas na linguística, e então propõe uma espécie de requisito mínimo para que algo seja considerado "escrita completa": 1) deve ter como objetivo a comunicação; 2) deve consistir de marcas gráficas artificias em uma superfície; 3) a escrita deve usar marcas que se relacionem convencionalmente para articular a fala, a fim de que a comunicação seja alcançada (FISCHER, 2009). Logo, a relação das marcas simbólicas com a fala - ou seja, com a voz - é um de seus requisitos para a escrita "completa". Há, porém, escritas que não preenchem os três requisitos: são ainda assim consideradas "escritas", mas "incompletas".

Comecemos então pelas escritas que "não tem relação com a voz”. São talvez as mais interessantes, uma vez que, a despeito de sua limitação, se configuram de modo muito diferente das escritas que conhecemos. Por não terem relação com a "fala", não são consideradas por Fischer "escritas completas". O primeiro tipo é o registro com nós, os chamados Quipu. Trata-se de uma longa corda com nós coloridos ou simples, representando o tipo de mercadoria e a quantidade. Era um instrumento para a lembrança de quantidades, uma ferramenta para a contabilidade. Também para contabilidade serviam os "entalhes". Entalhes são pequenos cortes em uma superfície para armazenar determinada informação. Há ossos entalhados que sugerem os ciclos da lua, outros que sugerem a quantidade de ancestrais de uma determinada tribo. De todo modo, serviam para armazenar - contabilmente - alguma percepção humana. Já os "registros de contas" são pequenos entalhes de diferentes tamanhos para se referir a diversas quantidades. Em geral, quanto maior a quantidade, maior a madeira retirada no entalhe. Como se vê, as escritas que não possuem relação direta com a voz destinam-se a contabilidade, ao registro de quantidades.

destruição e de construção" (GAGNEBIN, 2009, p. 17).

${ }^{4}$ Para evitar o excesso de referências no corpo do texto, notificamos ao leitor que todas as referências sobre as escritas contábeis, escritas pictóricas e escritas fônicas deste trabalho podem ser encontradas no livro de S. R. Fischer $(2009$, p. 13-32), História da escrita, no capítulo intitulado "Dos entalhes às tabuletas". 
Para além das escritas puramente contábeis, há as escritas pictóricas. Nossos ancestrais, vendo as limitações das cordas e entalhes, precisaram em certo momento de uma variedade maior de recursos. A imagem foi sua próxima descoberta: criaram "a escrita pictográfica”. Um pictograma pode tanto ser um simples desenho de um único objeto ou ser (como um cavalo), mas também a mistura de vários elementos (um cavalo, uma árvore e uma mulher). Ao contrário do que pode parecer à primeira vista, um pictograma é capaz de passar uma mensagem muito complexa juntando diferentes imagens. A pictografia não é, entretanto, escrita completa. Ela visa à comunicação, está em uma superfície durável, porém não está ligada diretamente à voz. A diferença é tênue, mas existe: a imagem pictográfica é reconhecida como imagem. Não há referência direta a um fonema, isto é, a escrita pictográfica não articula uma fala através da imagem.

Ainda nas escritas pictóricas, misturando pictografia e contabilidade, chegamos às "fichas de argila". $\mathrm{Na}$ região da Suméria - atual Iraque - e arredores, fichas de argila com símbolos eram utilizadas para a contagem de mercadorias. Tomemos como exemplo dez ovelhas: em uma ficha, desenhava-se o símbolo de uma ovelha. Bastava então inscrever isso em mais nove fichas e, enfim, eis as dez ovelhas representadas. Punham-se todas as fichas em um envelope de argila (bulla) e imprimia-se um símbolo que representava as dez fichas no interior do envelope. Pela primeira vez na história, havia um símbolo de um símbolo, ou seja, uma referência indireta. O primeiro mais largo afastamento do objeto através da escrita se deve a essa técnica.

Ora, mas o passo decisivo em direção à escrita completa foi a "fonetização sistêmica". A fonetização começou de maneira tímida. Primeiro, pela própria elaboração da comunicação pictórica, mal se podia reconhecer o objeto que era representado pelo símbolo. A representação de um jacaré deixava de ser a de um animal com rabo longo, patas curtas e boca grande e cheia de dentes para se tornar uma abstração, uma linha reta com pontos (em um exemplo fictício). Depois, o pictograma começou a descrever coisas diferentes: "pé" era tanto "pé" quanto "andando", "boca" era tanto "boca" quanto "fala". Até o ponto de complexidade em que um triângulo com duas colinas tinha se transformado em "mulher estrangeira".

Deste modo, também na região da Suméria, “o valor fonético de um símbolo começou a superar seu valor semântico" (FISCHER, 2009, p. 14). Foi assim que em um exemplo aproximativo para a nossa língua - a palavra "papel" passou a ser representada por dois símbolos: um, que representava uma "pá", e outro, que representava uma "pele". Logo: pá-pele, papel. Fez-se então a escrita completa: comunicava, estava impressa e usava marcas convencionais para articular a fala. Essa ideia aparentemente simples se espalhou até culminar em uma escrita "exclusivamente fonética", que nada tinha de pictórica. O poeta e historiador da escrita Georges Jean (2002, p. 18) nos resume:
A escrita, nascida tão modestamente por exigências da simples contabilidade, vai tornando-se, pouco a pouco, para os habitantes da Mesopotâmia, um sumário, um auxílio; depois uma maneira de guardar vestígios da língua falada; e, sobretudo, uma outra maneira de comunicá-la e até mesmo de pensar e de se expressar.

Assim, a escrita aparece primeiramente como um "registro" contábil, depois como uma "extensão da memória", então se torna uma "extensão da própria voz" e por fim uma "transmutação da voz" até certo ponto autônoma frente à voz que lhe originou.

\section{Da extensão da própria voz à transmutação da voz}

O caminho entre a escrita como "extensão da própria voz" até a escrita como "transmutação da voz" foi bem longo. Não só fatores políticos mas sobretudo técnicos permitiram que se chegasse a uma leitura silenciosa e igualmente a uma escritura que fosse além do simples recolhimento e articulação da voz audível.

No mundo greco-latino, de modo geral, a escrita não passava de um registro da voz: o mais comum é que se ditasse a escribas (LE GOFF, 2008, p. 32-37). No dizer de Fischer (2009, p. 209), “A literatura era principalmente um auxiliar da memória, recordando o que já se tinha ouvido em algum lugar". Ao que indicam os tantos exemplos fornecidos pelo historiador J. Balogh, a experiência da leitura sem o acompanhamento da voz era vista como algo extraordinário na Antiguidade. No que concerne à técnica, o material para a leitura e escritura consistia em rolos de papiro, nos documentos mais importantes -, na tábua de cera ou pedra. Segundo Jacques Le Goff (2008, p. 34), o próprio rolo era um empecilho à leitura interior, uma vez que exigia uma "manipulação mais longa", dificultando as remissões rápidas a páginas anteriores. Le Goff (2008, p. 35) acredita que "o rolo quase não favorece a leitura silenciosa". Deste modo, a autoridade e o pensamento permaneciam concentrados na voz e o fato de estar escrito ou não era secundário.

Ocorre então na Idade Média uma grande virada. Bem a conhecemos pelo famoso assombro de Santo Agostinho com seu mestre Ambrósio. A razão do susto era a mais ordinária para nós: Ambrósio lia silenciosamente. Santo Agostinho (2011, p. 119) nos relata o acontecimento: "Quando lia, os olhos divagavam pelas páginas e o coração penetrava-lhes o sentido, enquanto a voz e a língua descansavam. Nas muitas vezes que me achei presente [...] sempre o via ler em silêncio e não de outro modo". Essa descrição marcava uma mudança que foi originada na Idade Média - apenas nos círculos mais cultos: a função da escrita passou do simples registro de uma voz para se tornar o próprio pensamento (FISCHER, 2009, p. 210).

Para esta virada na leitura e na escrita, três fatores foram responsáveis: a invenção do pergaminho, material que poderia ser cortado em páginas; a criação do livro - o então chamado códex - que era muito mais fácil de manipular e deixava o corpo do escritor sem os rolos nas mãos; e, bem mais tarde, a criação das universidades, que tornou a escrita "irregular, personalizada, com um sistema de abreviações” (LE GOFF, 2008, p. 37). Le Goff 
(2008, p. 37) nos fornece ainda o exemplo de Tomás de Aquino e sua letra cursiva incompreensível, na qual se sente "a louca rapidez do pensamento no momento de nascer". Se antes a escrita estava condicionada pelo andamento rítmico da voz, agora a escrita pode tornar-se até mais rápida que a voz.

$\mathrm{Na}$ cultura medieval ocorre o primeiro encontro íntimo entre a voz e a escritura. A transição da leitura altissonante para a leitura silenciosa caminha em passo igual com a transição de uma cultura escrita - onde a escrita registra a voz - para uma cultura letrada, onde "toda expressão é marcada mais ou menos pela presença da escrita" (ZUMTHOR, 1993, p. 18). O desenvolvimento técnico da imprensa e o invento do papel - ainda que sejam transformações radicais em termos de ampliação do saber - parecem não ter mais que consolidado o que a cultura medieval nos trouxe de novo nas relações entre voz e escrita.

\section{A relação da escrita com voz}

A escrita até hoje serve a muitos destinos. Como leitores e escritores comuns, bem sabemos que a escrita nos auxilia a fazer contas, a lembrar de compromissos. Mas o poder que a nós parece mágico da escrita é a sua relação com a voz. Há nitidamente, quando lemos, a intuição de que a voz de alguém nos fala no instante da leitura. É certo que ela toma os sons segundo a vida de cada um, mas ainda assim a escrita evoca - dependendo do modo como for trabalhada - uma emoção que ultrapassa o sentido explícito da frase. O poeta britânico A. Alvarez, em seu livro $A$ voz do escritor, argumenta:

A literatura tem a ver com escutar uma voz. Quando você lê um romance, uma voz está lhe contando uma história, quando lê um poema, ele geralmente fala sobre o que o dono dessa voz está sentindo; mas nem o meio nem a mensagem são o principal aqui. O principal é que essa voz é diferente de qualquer outra que já se tenha escutado, e ela está falando diretamente com você que lê, comungando com você em particular, bem no seu ouvido, e no seu jeito todo peculiar (ALVAREZ, 2006, p.18).

A voz da escrita é o que excede o sentido no instante da transmissão. É sobretudo uma outra presença onde a presença de sentido - se não é irrelevante - é sem dúvida menor. ${ }^{5} \mathrm{~A}$ ambição primeira da escrita talvez tenha sido a de ser salvadora do sentido. Pela escrita, pode-se circunscrever o sentido das palavras através da materialidade das palavras em papel, grafando signos. Em termos mais simples, o escritor se utiliza de palavras, e as palavras naturalmente tem sons. Mas esses sons, que deveriam indicar simplesmente um sentido claro, sempre extrapolam o sentido. Assim, quando a escrita busca salvar sua origem - ou seja, salvar a voz - ela não pode simplesmente salvar o sentido, ou ainda, ela não pode tão só salvar a materialidade fônica que é colada ao sentido. Ela salva também algo que não busca significar.

\footnotetext{
${ }^{5}$ Há uma outra qualidade importante desta voz: trata-se de uma "presença" que nos evidencia sua própria "ausência". Pode-se dizer, após Maurice Blanchot, que a voz, no espaço literário, é a afirmação da "presença de sua própria ausência". Para mais: Blanchot (1987, p. 21).
}

Fractal, Rev. Psicol., v. 29 - n. 3, p. 231-238, 2017
De modo geral e linear, a escrita teve seu primeiro uso na literatura no registro de canções e histórias; depois, evoluiu para a emulação de uma voz que contava; e só então a escrita tomou seu destino próprio, sem precisar se referir explicitamente ao instante da performance. Até hoje, a literatura ainda não descobriu um modo de escrever o que é impossível para a voz humana. Mesmo os textos mais extremos de Samuel Beckett, mesmo o James Joyce (2004) de Finnegans Wake, todos eles são sem sentido, sem dúvida, mas pronunciáveis. A única escrita que é impronunciável é a dos símbolos, como o ponto de interrogação, a vírgula, o asterisco; mas até hoje, por mais futura que fosse a vanguarda, não consta que houvesse um romance inteiro de símbolos. Isto, sem dúvida, nos faria crer em uma "materialidade da voz" que se situa na origem da escrita, que se evidencia pelo simples fato de que todo escrito é pronunciável. Em relação à escrita literária, é possível afirmar sem muitos problemas que ela captura a materialidade da voz, isto é, que captura os fonemas. Mas como dissemos, por capturar a materialidade, será que ela deixa de capturar o que na voz excede o material?

Ora, a caligrafia, a tipografia, a qualidade do papel, o tipo da caneta ou do teclado de computador, se o livro tem notas ou não, enfim, tudo isso excede o sentido mas não é voz. Tudo isso "excede o sentido", mas é "material". O que buscamos nesta nossa inquirição é se a escrita é capaz de capturar o que "excede o sentido" e é ao mesmo tempo "imaterial".

\section{Leitura}

É bem provável que, se pensarmos sobre o próprio ato de leitura - que é onde tudo isso acontece -, chegaremos a alguma revelação, ainda que mínima. $\mathrm{O}$ único fato que sabemos é esse: no ato da leitura ocorre uma estranha síntese. Como diz Alvarez (2006, p. 18), "É um pacto de mão-dupla: o escritor se faz ouvir e o leitor lhe dá ouvidos - ou, mais precisamente, o escritor trabalha para criar ou encontrar uma voz que irá alcançar o leitor, fazendo-o apurar ouvidos e prestar atenção". As vozes do passado salvas pela escritura se encontram - em harmonia ou não - com as vozes possíveis do presente.

A voz de um determinado texto consiste em todas as possibilidades vocais que ele pode incitar. São muitíssimas, sem dúvida; mas definitivamente não são todas. Assim, se lemos "O livro das ignorãças" de Manoel de Barros (2010), nas letras impressas estão contidos não apenas os fonemas daquele texto, mas também todas as vozes possíveis de leitura, todas as alturas, todos os tons, a leitura sussurrada ou o grito revoluto, etc., para aquele texto. Sobretudo nas obras onde o sentido não é o que se busca de imediato - que é obviamente o caso de Manoel de Barros -, perguntar pelos atributos "imateriais" da voz na literatura se torna uma ineludível tarefa.

A imaterialidade da voz originada na escrita é tudo o que ouvimos na leitura silenciosa. Se por acaso lemos um texto, por direto e claro que seja, não raro escutaremos uma voz a narrar esse texto. Esta imagem é, aliás, muito comum em filmes, quando uma pessoa lê, por exemplo, uma carta de despedida e a voz do personagem que es- 
creveu a carta declama-a, com sua emoção própria. Essa voz notadamente imaterial que nos narra um escrito não é irreal. Ela é real. "Imaterialidade não coincide com irrealidade". A voz que ouvimos no instante da leitura não pode ser vista de outro modo senão como uma alucinação auditiva do ponto de vista material, mas ela é certamente real para nós - caso nossa premissa esteja certa, isto é, que nós ouvimos uma voz no momento da leitura.

Há outro ponto igualmente importante: como se chega à voz de leitura? Em termos de voz, o leitor não recebe nada. O leitor "encontra-se": assim como nos encontramos em algum lugar ou como um bebê encontra-se na língua de sua mãe. Se o leitor é do mesmo idioma que o escritor, as ruínas da voz que lhe deixou o escritor são - em parte - as suas ruínas; ele as reconhece. Certamente, ele não terá jamais ouvido a frase exata à qual "está" agora; porém, não é de frases mas de ruínas que se trata.

A transmissão da experiência através da escrita é um encontro entre a voz criada por aquele que escreveu com a voz que o leitor empresta ao escrito. Ou seja, há um encontro entre a criação a partir das ruínas do escritor com as ruínas que o leitor dispõe até que ambas as vozes se tornem uma "voz original". Ler um texto do século XVI nos parece um belo exemplo. Apesar de legível, a voz criada pelo escritor não coincide com a nossa. Tudo o que foi criado - ainda que com a intenção de ser o mais acolhedor dos universos - é extremamente inóspito para nós. Nesse momento, nada como uma adorável professora de literatura, que com sua voz suave nos possa, através da leitura altissonante, nos proporcionar mais ruínas. No próximo texto do mesmo século, quase a ouviremos recitar para nós em nossa leitura silenciosa. No décimo texto, algumas frases e nada mais. Dez anos depois, o mais provável é que, ao lermos, tudo o que lembraremos é que uma professora de voz adorável nos introduziu aos poemas. Mas a sua voz... Como ter certeza de sua voz? Assim se criam as ruínas vocais, que começam sempre pessoais até se desmancharem em uma voz impessoal, original. E é com essa "voz original" que o leitor lê o que está escrito. A voz não está lá de modo completo desde que aprendemos uma língua, a origem não é pronta desde o princípio: a origem é o que - sem cessar, e ainda hoje "acumula ruína sobre ruína e as dispersa aos nossos pés" (BENJAMIN, 1994, p. 266).

\section{Escritura}

O trabalho do escritor, por outro lado, consiste em acessar a voz que está na origem da escrita. Há pouco falamos da "virada medieval", que tornou possível a leitura silenciosa. Ler silenciosamente fez com que o componente fônico - que era claramente material e até mensurável em um estúdio de gravação - se partisse em duas fontes na escrita: 1) uma parte que é material, os "símbolos que representam sons", 2) e outra parte que é imaterial (ou de matéria mais escusa), os "sons da voz que recebemos mediadamente" pelas letras impressas. Nenhum escritor ignora que a escrita pressupõe um embate entre o que é escrito em um papel e os sons dessa escrita - incluindo todas as nuances da performance, o grito, o erro, os tons de voz.
O escritor trabalha para acessar a origem da escrita. O que isto quer dizer? Guimarães Rosa, apesar de sabidamente anotar as palavras sertanejas em suas longas viagens pelo sertão, não era um transcritor da fala do Sertão. Ele não fazia, por exemplo, uma escrita mais antropológica, como um Jorge Icaza (1978), que mantinha notas de rodapé explicitando o significado de tal ou qual palavra. Foi a partir de tantas ruínas vocais - não apenas da fala sertaneja mas também das vozes de tantas línguas que estudou - que Rosa se viu capaz de salvar uma voz que é a possibilidade de recriação de toda a materialidade e imaterialidade sonora segundo novas ordens. Esta é a operação da escrita. É a criação de um novo "universo", que, com suas regras próprias, se expande infinitamente - se acaso nos lembramos do final de Grande Sertão: Veredas (ROSA, 2009).

Ao que tudo indica, quem regula as leis desse universo - as leis da física, digamos - é o sentido. O sentido é, sem dúvida, o que se configura como logos, como aquilo que é compartilhado entre as pessoas de uma comunidade. Dizer que o escritor se encontra atravessado pelo sentido na composição de sua obra é um modo mais simples de dizer que o ele se vê enredado em uma série de fatalidades e escolhas, que poderíamos sem dúvida chamar de "políticas".

Uma voz não se cria sem política. Não apenas as estruturas econômicas de uma sociedade definem essas ruínas fônicas mas igualmente seu desenvolvimento técnico, suas estratégias de poder e a ética que a ela pertence. O suporte no qual o autor escreve, para quem ele escreve, por que ele escreve, com que métodos ele escreve, onde ele aprendeu a escrever, com quem ele conversava, o que ele fazia, era pobre ou rico, viveu em paz ou em um campo de concentração, foi senhor ou escravo, foi financiado ou definhou de fome, ditou a um escriba ou escreveu em um computador, foi casado ou Casanova: toda a vida política do escritor o levam não só a escutar certas ruínas materiais de seu idioma mas também o incitam a escolher algumas e ignorar outras. Que fique claro, elas “incitam”, mas não "determinam”, uma vez que essa escolha não é necessariamente uma escolha consciente do escritor. "Como os sonhos", disse Alvarez (2006, p. 34), "a [voz] fala por partes de você de cuja existência você não se dá conta e das quais pode não gostar [...]. Entretanto, se você tentar expurgá-las, irá privar de vida o que tem a dizer". Se o mesmo poeta chama essa voz de "subversiva", no sentido de não poder ser jamais dominada completamente, seu juízo não é nem um pouco equivocado. Nada é mais imprevisível que a voz literária - nunca se sabe exatamente como o autor quis se fazer ouvido e tampouco como o leitor escutará o texto.

\section{Leitura e escritura}

Entre o escritor e o leitor há um ponto que os une, sem dúvida; porém, é o mesmo que os separa. É o que impede o texto de se esgotar. Há uma espécie de abismo sobre o qual ambos buscam erguer uma ponte, cada um a seu lado, até que possam se comunicar. Essa ponte inclui materiais muitíssimo heterogêneos, e não está jamais completa. Assim pensa o escritor Alberto Manguel (1997, p. 
112, grifo do autor): "cada texto precisa ser inacabado (ou abandonado, como sugeriu Paul Valery). Na verdade, um texto pode ser lido somente "porque" é inacabado, deixando assim espaço para o trabalho do leitor". Também o escritor Ítalo Calvino (2009, p. 190) afirma que "o escritor [...] tem de pressupor um leitor que ainda não existe, ou uma mudança no leitor assim como ele é hoje". Nós, enquanto leitores, não temos as mesmas vozes que um escritor teve ao criar sua obra. Igualmente, quando escrevemos, também não podemos esperar que alguém leia com nossas vozes - até mesmo porque, se lemos um texto que escrevemos alguns anos atrás, que voz estranha era aquela! Cada leitor evolui seu dialeto de leitura assim como cada escritor elabora sua voz de escrita. Ambos trabalharam e ainda trabalham para isso.

\section{Aniquilação}

No início, dissemos que a origem tem ao mesmo tempo uma intensidade salvadora e uma intensidade destruidora. Sobre a salvadora, já tratamos bastante. A escrita salva a voz, tanto o material (os fonemas) quanto "parte" do que é imaterial. Se alguém transcrevesse uma palestra, sem dúvida salvaria a voz do palestrante para o futuro. Porém, é bastante evidente que, no instante em que se a escreve, a voz perde sua força performática. É aqui que surge a intensidade destruidora, ou como preferimos chamar, a "aniquilação".

Walter Benjamin (2004, p. 198) disse certa vez que as melhores histórias escritas eram as que mais se pareciam com as transmitidas oralmente - talvez porque tivesse clara consciência do poder aniquilador que pode ter a escrita ao tentar lidar com a voz. A escrita pode naturalmente emular um gesto performático, por exemplo, utilizando maiúsculas para representar um texto gritado. No entanto, ela não tem o mesmo poder de um berro por maiores que sejam as letras. Um choro, quando escrito, só precariamente é representado. Porém, não é imprudente dizer que o choro é voz, na medida em que, como bem se sabe, pode-se falar chorando. Isso é bem evidente, parece: a escrita aniquila a voz. A escrita subtrai o poder da voz, tira sua potência. A escrita arruína a voz. Não se deve tomar 'arruinar' pelo lado negativo, pois o caráter destruidor da escrita abre espaço para usos inteiramente novos da voz que a voz, ela mesma, jamais poderia alcançar por si própria.

Fazer as letras vibrarem como a voz talvez seja o mais presente trabalho do escritor. Não se trata, naturalmente, de imitar uma voz, mas, sim, um trabalho com as ruínas da voz que ainda resistem no escrito. Mas não se chega até as ruínas sem passar pela aniquilação da voz que parece se encontrar na origem mesma de toda operação de escrita.

\section{Considerações finais}

A escrita é um processo de salvação da voz, eis a nossa conjectura. Mas não sabemos se é possível generalizar e dizer que toda escrita é a salvação de uma voz. Gostaríamos apenas não perder de vista que ela bem pode ser isso, e que há consequências. A partir do momento em que foi escrita, nem a voz nela salva permanece a mesma, nem a escrita pode se desvencilhar da voz. Já a escrita não tem o poder, naturalmente, de preservar toda a intensidade emotiva vocal, mas de certo torna possível um resgate parcial (material e imaterial) da voz que está na origem - voz esta que seria muito mais poderosa caso estivesse ainda concentrada na performance. A escrita salva a voz, restituindo sua potência e destituindo o seu poder.

\section{Referências}

AGOSTINHO, St. Confissões. Petrópolis, RJ: Vozes, 2011.

ALVAREZ, A. A voz do escritor. Rio de Janeiro: Civilização Brasileira, 2006.

ATKINS, P. On Being: a scientist's exploration of the great questions of existence. Oxford: Oxford University Press, 2011.

BARROS, M. O livro das ignorãças. In: completa. São Paulo: Leya, 2010. p. 297-324. Poesia

BENJAMIN, W. O narrador: considerações sobre a obra de Nicolai Leskov. In: Magia e técnica, arte e política: ensaios sobre literatura e história da cultura. São Paulo: Brasiliense, 2004. Obras escolhidas, v. 1, p. 197-221.

BENJAMIN, W. Sobre o conceito de história. In: Magia e técnica, arte e politica: ensaios sobre literatura e história da cultura. São Paulo: Brasiliense, 1994. Obras escolhidas, v. 1, p. 222-234.

BLANCHOT, M. O espaço literário. Rio de Janeiro: Rocco, 1987.

CALVINO, I. Assunto encerrado: discursos sobre literatura e sociedade. São Paulo: Companhia das Letras, 2009.

FEYERABEND, P. Contra o método. São Paulo: Unesp, 2011.

FISCHER, S. R. História da Escrita. São Paulo: Unesp, 2009.

GAGNEBIN, J. M. História e narração em Walter Benjamin. São Paulo: Perspectiva, 2009.

GODFREY-SMITH, P. Theory and Reality: an introduction to the philosophy of science. Chicago: University of Chicago Press, 2003.

HEGEL, G. W. F. The Philosophy of History. London: Encyclopædia Britannica, 1971. Great Books of the Western World, v. 46, p. 153-370.

ICAZA, J. Huasipungo. Rio de Janeiro: Paz e Terra, 1978.

JEAN, G. A escrita: memória dos homens. São Paulo: Objetiva, 2002.

JEANROY, A. La poésie lyrique des troubadours. Paris: Henri Didier, 1934. v. 1.

JOYCE, J. Finnegans Wake / Finnícius Revém. Cotia, SP: Ateliê, 2004.

KLEE, P. Angelus Novus. Oil transfer and watercolor on paper, $31.8 \times 24.2 \mathrm{~cm}(12.5 \times 9.5 \mathrm{in})$, CC BY-SA 3.0. Jerusalem: The Israel Museum, 1920. Disponível em: $<$ https://commons. wikimedia.org/w/index.php?curid=25188355>. Acesso em: 12 jun. 2013.

LE GOFF, J. Em busca da Idade Média. Rio de Janeiro: Civilização Brasileira, 2008.

MANGUEL, A. Uma história da leitura. Companhia das Letras: São Paulo, 1997. 
ROSA, G. Grande Sertão: Veredas. In: COUTINHO, E. (Org.).

Ficção completa. Rio de Janeiro: Nova Aguilar, 2009. v. 2, p. 5-395.

RUTHVEN, K. K. Myth. Cambridge: Taylor \& Francis, 1976.

ZUMTHOR, P. A letra e a voz: a "literatura" medieval. São Paulo: Companhia das Letras, 1993.

Recebido em: 28 de agosto de 2013

Aceito em: 20 de setembro de 2017 